\title{
Pre-operative Prediction of Difficult Laparoscopic Cholecystectomy
}

\author{
Mukund Raj Joshi, ${ }^{1}$ Tanka Prasad Bohara, ${ }^{1}$ Shail Rupakheti, ${ }^{1}$ Anuj Parajuli, ${ }^{1}$ Dipendra Kumar Shrestha, ${ }^{2}$ \\ Dimindra Karki, ${ }^{1}$ Uttam Laudari' \\ 'Department of Surgery, Kathmandu Medical College Teaching Hospital, Kathmandu, Nepal, ${ }^{2}$ Department of Surgery, \\ Lumbini Medical College and Teaching Hospital, Palpa, Nepal.
}

Introduction: Laparoscopic cholecystectomy (LC) is one of the most common operation performed. Though LC have become safer and easier at times it can be difficult. Difficult cases can result in prolonged operative time, bleeding, bile spillage, conversion to open technique and bile duct injury resulting in unplanned prolonged hospital stay, increase in estimated cost to the patients and for the surgeon it leads to increased stress during operation and time pressure to complete the operative list. . Identification of difficult cases has potential advantages for surgeons, patients and their relatives. We aim to develop and validate a scoring system to predict difficult LC preoperatively.

Methods: Prospective study. History, physical examination, abdominal ultrasound and biochemical parameters were included to develop a scoring system. Hundred patients undergoing LC were included and preoperative scores were calculated preoperatively to predict difficult LC which was compared with operative assessment.

Results: Sensitivity and specificity of the preoperative scoring for difficult case was $53.8 \%$ and 89.2 $\%$ respectively with PPV of $63.64 \%$ and NPV of $84.62 \%$. Only three parameters (history of acute cholecystitis, gall bladder wall thickness and contracted gall bladder) were statistically significant to predict difficult LC individually. Area under ROC curve was 0.779 (95 \% CI, 0.657-0.883).

Conclusions: Preoperative scoring system can be used to predict difficult LC. Surgeons can plan operation based on predicted difficulty. Patients and relatives can be counselled preoperatively for the possibility of difficult operation, prolonged hospital stay and increased cost in predicted difficult case.

Keywords: Difficult cholecystectomy; Laparoscopic cholecystectomy; Symptomatic cholelithiasis

\section{INTRODUCTION}

Laparoscopic cholecystectomy (LC) is the gold standard treatment for symptomatic cholelithiasis. ${ }^{1}$ LC is the most frequently performed operation at our institute. With evolution in biomedical technology and improved quality of instruments LC has become easier and safer operation to perform. However, difficult case results in prolonged operative time, bleeding, bile spillage, conversion and bile duct injury. This leads to unplanned prolonged hospital stay and increase in estimated cost to the patients and increased stress to the surgeon and pressure to complete the operative list.

Correspondence: Dr. Mukund Raj Joshi, Department of Surgery, Kathmandu Medical College Teaching Hospital, Kathmandu, Nepal. Email: mukundraijoshi@gmail.com, Phone No: +977-9851008493. 
Pre-operative prediction of difficult cases has potential advantages for the surgeons, patients and their relatives.

We conducted the study with an aim to develop and validate a scoring system to predict difficult laparoscopic cholecystectomy pre-operatively.

\section{METHODS}

A prospective observational cross sectional study was conducted at Department of Surgery, Kathmandu Medical College Teaching Hospital, Sinamangal, Kathmandu from 15 August 2014 to 31 December 2014. After an informed consent, 100 consecutive patients undergoing elective laparoscopic cholecystectomy for symptomatic cholelithiasis performed by one of the three experienced surgeons in a single unit were included. Patients who had common bile duct stones, who had additional procedure to be done along with laparoscopic cholecystectomy, patients who had conversion or delay because of anesthetic complications and equipment failure, operations performed by trainee under supervision and those patients who were unwilling to give consent for the study were excluded from the study.

A scoring system was developed which is a modification of scoring system proposed by Randhawa and Pujahari ${ }^{2}$ which included history, clinical and sonography findings. We added biochemical parameters to the scoring system, history of comorbid illness in history and contracted gallbladder in sonography scoring. Table 1

Table 1. Pre-operative Scoring system

\begin{tabular}{|c|c|c|c|c|c|c|c|}
\hline \multicolumn{2}{|l|}{ History } & \multirow{3}{*}{$\begin{array}{l}\text { Score } \\
0 \\
1 \\
\end{array}$} & \multirow{3}{*}{\begin{tabular}{|l|}
$\begin{array}{l}\text { Maximum } \\
\text { score }\end{array}$ \\
1 \\
\end{tabular}} & \multirow{4}{*}{\begin{tabular}{|l} 
Clinical \\
Body Mass index
\end{tabular}} & & \multirow{3}{*}{\begin{tabular}{|l|} 
Score \\
0 \\
1 \\
\end{tabular}} & \multirow{2}{*}{\begin{tabular}{|l|}
$\begin{array}{l}\text { Maximum } \\
\text { Score }\end{array}$ \\
2 \\
\end{tabular}} \\
\hline \multirow{2}{*}{ Age in years } & $\leq 50$ & & & & $\leq 25$ & & \\
\hline & $>50$ & & & & $25-27.5$ & & \\
\hline \multirow{2}{*}{ Sex } & Female & 0 & \multirow[t]{2}{*}{1} & & $\geq 27.5$ & 2 & \\
\hline & Male & 1 & & \multirow{3}{*}{ Abdominal Scar } & No & 0 & \multirow[t]{3}{*}{2} \\
\hline \multirow{2}{*}{$\begin{array}{l}\text { History of Acute } \\
\text { cholecystitis }\end{array}$} & No & 0 & \multirow[t]{2}{*}{4} & & \begin{tabular}{|l|} 
Infra- \\
umbilical
\end{tabular} & 1 & \\
\hline & Yes & 4 & & & $\begin{array}{l}\text { Supra } \\
\text { Umbilical }\end{array}$ & 2 & \\
\hline \multicolumn{4}{|l|}{ Co-morbid illness } & \multirow{2}{*}{$\begin{array}{l}\text { Palpable Gall } \\
\text { Bladder } \\
\end{array}$} & No & 0 & 1 \\
\hline \multirow{2}{*}{ Diabetes Mellitus } & No & 0 & \multirow[t]{8}{*}{4} & & Yes & 1 & \\
\hline & Yes & 1 & & Biochemical & & & \\
\hline \multirow{2}{*}{$\begin{array}{l}\text { Chronic obstructive } \\
\text { airway disease }\end{array}$} & No & 0 & & \multirow{4}{*}{$\begin{array}{l}\text { White Blood Cell } \\
\text { Count Per cu mm }\end{array}$} & \multirow[t]{2}{*}{$\leq 11000$} & \multirow[t]{2}{*}{0} & \multirow[t]{4}{*}{1} \\
\hline & Yes & 1 & & & & & \\
\hline \multirow{2}{*}{$\begin{array}{l}\text { Congestive cardiac } \\
\text { Failure }\end{array}$} & No & 0 & & & \multirow{2}{*}{$\geq 11000$} & \multirow{2}{*}{1} & \\
\hline & Yes & 1 & & & & & \\
\hline \multirow{2}{*}{$\begin{array}{l}\text { Other Systemic } \\
\text { illness }\end{array}$} & No & 0 & & \multirow{2}{*}{ Total Bilirubin } & \multirow{2}{*}{$\leq 1.1$} & \multirow{2}{*}{0} & \multirow[t]{2}{*}{1} \\
\hline & Yes & 1 & & & & & \\
\hline \multicolumn{4}{|l|}{ Sonography } & & $\geq 1.1$ & 1 & \\
\hline \multirow{2}{*}{ Wall Thickness } & Thin $\leq 4 \mathrm{~mm}$ & 0 & \multirow[t]{2}{*}{2} & Alanine & $\leq 45$ & 0 & 1 \\
\hline & Thick $>4 \mathrm{~mm}$ & 2 & & Transaminase & $\geq 45$ & 2 & \\
\hline Peri-cholecystic & No & 0 & 1 & Aspartate & $\leq 45$ & 0 & 1 \\
\hline Collection & Yes & 1 & & Transaminase & $\geq 45$ & 1 & \\
\hline Impacted stone at & No & 0 & 1 & & $\leq 306$ & 0 & 1 \\
\hline neck of Gall bladder & Yes & 1 & & Alkaline & & & \\
\hline Contracted Gall & No & 0 & 1 & phosphatase & $\geq 306$ & 1 & \\
\hline Bladder & Yes & 1 & & & & & \\
\hline
\end{tabular}


Patients admitted for elective LC who were included in the study were assessed and their history, clinical examination and investigations were reviewed. Based on these findings preoperative risk score was calculated on the basis of above scoring method (Table 1) a day prior to surgery. Patients with scores of 0 to 5 were predicted as easy, patients with scores 6 to 15 and more than 15 were predicted as difficult and very difficult cases respectively. Pre-operative scores and prediction was blinded from operating surgeon.

All the operations were performed by one of the three experienced surgeons of a single surgical unit having more than four years of experience in laparoscopic operations. Surgery was done using carbon dioxide pneumoperitoneum with $14 \mathrm{~mm} \mathrm{Hg}$ pressure and using one $5 \mathrm{~mm}$ and two $10 \mathrm{~mm}$ ports. Time taken was noted from first port site incision till last port closure. Duration of surgery, bile/stone spillage, injury to duct/artery and conversion to open procedure were recorded. Per operative objective assessment was done as easy, difficult and very difficult by an independent observer based on the parameters as shown in Table 2.

Table 2. Per operative Assessment of Difficulty.

\begin{tabular}{|c|c|}
\hline EASY & $\begin{array}{l}\text { Time taken } \leq 45 \text { minutes } \\
\text { No bile spillage } \\
\text { No injury to duct / artery }\end{array}$ \\
\hline DIFFICULT & $\begin{array}{l}\text { Time taken } 46-90 \text { minutes } \\
\text { Bile/stone spillage } \\
\text { Injury to duct } \\
\text { No conversion to open procedure }\end{array}$ \\
\hline $\begin{array}{l}\text { VERY } \\
\text { DIIFICULT }\end{array}$ & $\begin{array}{l}\text { Time }>120 \text { minutes } \\
\text { Conversion to open procedure }\end{array}$ \\
\hline
\end{tabular}

Per operative assessment was compared with preoperative prediction based on the scores to calculate the sensitivity and specificity of the pre-operative scoring system.

All statistical analyses were performed using Statistical Package for the Social Science version 20. p value of $<0.05$ was accepted as statistically significant. Sensitivity and specificity was calculated for prediction of easy and difficult case using two by two tables. Area under ROC was used to find the predictive value of preoperative score for predicting the difficult case.

Ethical clearance was taken from the Research and Ethic committee of Kathmandu Medical College Teaching Hospital, Sinamangal, Kathmandu, Nepal.
Informed consent was taken from the patients.

\section{RESULTS}

Hundred patients were included in the study out of which 71 (71\%) were female and 29 (29\%) were male. Mean age was 42.15 years (14 - 78)

On the basis of preoperative scores 78 (78\%) patients were predicted to be easy, $22(22 \%)$ were predicted to be difficult and none of the cases were predicted to be very difficult. However, in per operative assessment 74 (74\%) were easy, 24 (24\%) were difficult and 2 (2\%) were very difficult.

Because there was no prediction of very difficult cases based on pre-operative scores and only $2(2 \%)$ cases were found to be very difficult, difficult and very difficult cases were combined for further analysis.

Table 3 shows the comparison of pre-operative prediction with per operative assessment of difficulty

For easy case, sensitivity and specificity of pre-operative prediction was $89.2 \%$ and $53.8 \%$ respectively whereas positive and negative predictive value was $84.62 \%$ and $63.64 \%$ respectively. Conversely for difficult case prediction, sensitivity and specificity of the scoring system was $53.8 \%$ and $89.2 \%$ respectively whereas negative and positive predictive value was $63.64 \%$ and $84.62 \%$ respectively.

Table 3. Comparison of pre-operative prediction with per-operative assessment of difficulty.

\begin{tabular}{|lccc|}
\hline & Per Operative Assessment & \\
Pre- & Easy & Difficult & \\
operative & $\begin{array}{c}\text { (Percentage of } \\
\text { pre-operative } \\
\text { Prediction }\end{array}$ & $\begin{array}{c}\text { (Percentage of } \\
\text { pre-operative } \\
\text { prediction) }\end{array}$ & Total \\
Easy & $66(84.61 \%)$ & $12(15.38 \%)$ & 78 \\
Difficult & $8(36.36 \%)$ & $14(63.63 \%)$ & 22 \\
\hline
\end{tabular}

Association of individual parameters with the prediction of difficult case was assessed using unadjusted binary logistic regression (Table 4). Of all the parameters only history of acute cholecystitis, gall bladder wall thickness and contracted gall bladder were statistically significant in prediction of difficult case. 


\begin{tabular}{|c|c|c|c|c|}
\hline Parameters & $\begin{array}{l}\text { Easy (Percentage } \\
\text { within the } \\
\text { parameter) }\end{array}$ & $\begin{array}{l}\text { Difficult } \\
\text { (Percentage } \\
\text { within the } \\
\text { parameter) }\end{array}$ & $\mathrm{OR}(95 \% \mathrm{CI})$ & P Value \\
\hline Age $\begin{aligned} & \leq 50 \text { years } \\
& >50 \text { years }\end{aligned}$ & $\begin{array}{l}52(74.3 \%) \\
22(73.3 \%)\end{array}$ & $\begin{array}{l}18(25.7 \%) \\
8(26.7 \%)\end{array}$ & $.952(.361-2.513)$ & .921 \\
\hline $\begin{array}{c}\text { Sex } \begin{array}{l}\text { Female } \\
\text { Male }\end{array}\end{array}$ & $\begin{array}{l}56(78.9 \%) \\
18(62.1 \%)\end{array}$ & $\begin{array}{l}15(21.1 \%) \\
11(37.9 \%)\end{array}$ & $.438(.171-1.124)$ & .0086 \\
\hline $\begin{array}{c}\text { History of Acute } \\
\text { Cholecystitis } \\
\text { Absent } \\
\text { Present }\end{array}$ & $\begin{array}{l}66(82.5 \%) \\
8(40.0 \%)\end{array}$ & $\begin{array}{l}14(17.5 \%) \\
12(60.0 \%)\end{array}$ & $.141(0.049-.410)$ & .000 \\
\hline $\begin{array}{r}\text { Diabetes } \\
\text { Absent } \\
\text { Present }\end{array}$ & $\begin{array}{l}70(74.5 \%) \\
4(66.7 \%)\end{array}$ & $\begin{array}{l}24(25.5 \%) \\
2(33.3 \%)\end{array}$ & $.686(.118-3.984)$ & .674 \\
\hline $\begin{array}{l}\text { CCF } \\
\text { Absent } \\
\text { Present }\end{array}$ & $\begin{array}{l}73(73.7 \%) \\
1(100 \%)\end{array}$ & $\begin{array}{l}26(26.3 \%) \\
0(0.0 \%)\end{array}$ & & 1.00 \\
\hline $\begin{array}{l}\text { Other IIIness } \\
\text { Absent } \\
\text { Present }\end{array}$ & $\begin{array}{l}58(76.3 \%) \\
16(66.7 \%)\end{array}$ & $\begin{array}{l}18(23.7 \%) \\
8(33.3 \%)\end{array}$ & $.621(.228-1.687)$ & .350 \\
\hline $\begin{aligned} \text { BMI } & \leq 25 \\
& 25-27.5 \\
& >27.5\end{aligned}$ & $\begin{array}{l}35(81.4 \%) \\
31(67.4 \%) \\
8(72.7 \%)\end{array}$ & $\begin{array}{l}8(18.6 \%) \\
15(32.6 \%) \\
3(27.3 \%)\end{array}$ & $\begin{array}{l}.610(.132-2.824) \\
1.290(.299-5.573)\end{array}$ & $\begin{array}{l}.527 \\
.733\end{array}$ \\
\hline $\begin{array}{c}\text { Abdominal Scar } \\
\text { Absent } \\
\text { Infraumilical } \\
\text { Supraumbilical }\end{array}$ & $\begin{array}{l}62(74.7 \%) \\
11(68.8 \%) \\
1(100.0 \%)\end{array}$ & $\begin{array}{l}21(25.3 \%) \\
5(31.2 \%) \\
0(0.0 \%)\end{array}$ & & $\begin{array}{l}1.00 \\
1.00\end{array}$ \\
\hline $\begin{array}{l}\text { Palpable Gallbladder } \\
\text { Absent } \\
\text { Present }\end{array}$ & $\begin{array}{l}73(74.5 \%) \\
1(50.0 \%)\end{array}$ & $\begin{array}{l}25(25.5 \%) \\
1(50.0 \%)\end{array}$ & $.342(.21-5.681)$ & .455 \\
\hline $\begin{aligned} \text { WBC } & \leq 11000 / \mathrm{cu} \mathrm{mm} \\
& >11000 / \mathrm{cu} \mathrm{mm}\end{aligned}$ & $\begin{array}{l}72(74.5 \%) \\
2(50.0 \%)\end{array}$ & $\begin{array}{l}24(25.0 \%) \\
2(50.0 \%)\end{array}$ & $.333(.044-2.497)$ & .285 \\
\hline $\begin{array}{l}\text { Total Bilirubin } \\
\leq 1.1 \mathrm{mg} \% \\
>1.1 \mathrm{mg} \%\end{array}$ & $\begin{array}{l}67(74.4 \%) \\
7(70.0 \%)\end{array}$ & $\begin{array}{l}23(25.6 \%) \\
3(30.0 \%)\end{array}$ & $.801(.191-3.357)$ & .762 \\
\hline $\begin{aligned} \text { AST } & \leq 45 \mathrm{IU} / \mathrm{L} \\
& >45 \mathrm{IU} / \mathrm{L}\end{aligned}$ & $\begin{array}{l}68(77.3 \%) \\
6(50.0 \%)\end{array}$ & $\begin{array}{l}20(22.7 \%) \\
6(50.0 \%)\end{array}$ & $.294(.0851 .013)$ & .0052 \\
\hline $\begin{aligned} \mathrm{ALT} & \leq 45 \mathrm{IU} / \mathrm{L} \\
& >45 \mathrm{IU} / \mathrm{L}\end{aligned}$ & $\begin{array}{l}67(76.1 \%) \\
7(58.3 \%)\end{array}$ & $\begin{array}{l}21(23.9 \%) \\
5(41.7 \%)\end{array}$ & $.439(.126-1.523)$ & 0.196 \\
\hline $\begin{aligned} \mathrm{ALP} & \leq 45 \mathrm{IU} / \mathrm{L} \\
& >45 \mathrm{IU} / \mathrm{L}\end{aligned}$ & $\begin{array}{l}68(73.1 \%) \\
6(85.7 \%)\end{array}$ & $\begin{array}{l}25(26.9 \%) \\
1(14.3 \%)\end{array}$ & $2.206(.253-19.244)$ & .474 \\
\hline $\begin{array}{l}\text { Gall Bladder Wall Thicknes } \\
\quad \leq 4 \mathrm{~mm} \\
>4 \mathrm{~mm}\end{array}$ & $\begin{array}{l}72(78.3 \%) \\
2(25.0 \%)\end{array}$ & $\begin{array}{l}20(21.7 \%) \\
6(75.0 \%)\end{array}$ & $.093(.17-.494)$ & .005 \\
\hline $\begin{array}{l}\text { Pericholecystic fluid } \\
\text { Absent } \\
\text { Present }\end{array}$ & $\begin{array}{l}73(73.7 \%) \\
1(100.0 \%)\end{array}$ & $\begin{array}{l}26(26.3 \%) \\
0(0.0 \%)\end{array}$ & & 1.00 \\
\hline $\begin{array}{c}\text { Impacted stone at neck } \\
\text { Absent } \\
\text { Present }\end{array}$ & $\begin{array}{l}61(75.3 \%) \\
13(68.4 \%)\end{array}$ & $\begin{array}{l}20(24.7 \%) \\
6(31.6 \%)\end{array}$ & $.710(.239-2.115)$ & .539 \\
\hline $\begin{array}{c}\text { Contracted Gall bladder } \\
\text { Absent } \\
\text { Present }\end{array}$ & $\begin{array}{l}68(79.1 \%) \\
6(42.9 \%)\end{array}$ & $\begin{array}{l}18(20.9 \%) \\
8(57.1 \%)\end{array}$ & $.199(.061-.646)$ & .007 \\
\hline
\end{tabular}




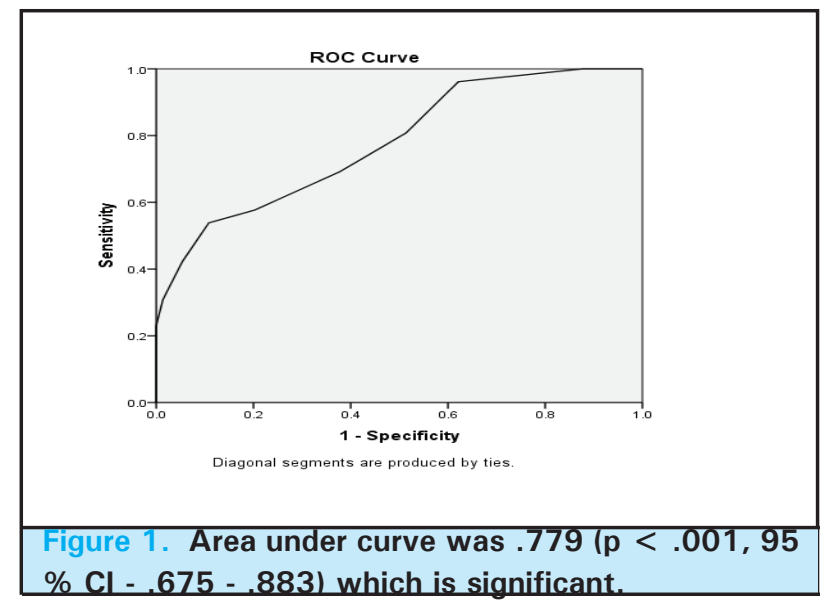

\section{DISCUSSION}

Pre-operative prediction of difficult laparoscopic cholecystectomy has potential advantages for surgeons, patients and their relatives. ${ }^{2-4}$ Surgeons may plan the operative list for the day based on the predicted difficult cases, to avoid time pressure if there is prolonged operative time in a difficult case and avoid unexpected conversion. This may help assign difficult case to an experienced surgeon with an equally experienced assistant. It is particularly applicable in places where most of the surgeons practice individually. Surgeon can seek for an experienced assistant or a senior colleague to accompany in a predicted difficult case. Hence the overall operative performance is not stressful to the surgeons and patients.

A difficult laparoscopic cholecystectomy can result in conversion to open procedure. Advantages of laparoscopic operation such as less pain, early recovery and return to work, less hospital stay and better cosmetics etc. are lost if operation is converted to open procedure. Conversion to open procedure is dependent on the patient's factors as well as experience of the surgeon and team. So the proper assignment of predicted difficult case to an experienced surgeon and team will definitely results in lesser conversion and higher benefits to such patients which has also been shown by Takegami et al. ${ }^{5} \mathrm{~A}$ predicted easy case can be operated as day care surgical case and can be offered a newer technique such as single incision laparoscopic surgery (SILS) and natural orifice transluminal endoscopic surgery (NOTES). ${ }^{4}$

Patients may be counseled preoperatively about the possible difficult operation, prolonged hospital stay and possibility of conversion beforehand so that they are mentally prepared for that. Patient's relatives can also plan accordingly in a predicted difficult case keeping in mind the possibility of prolonged hospital stay and increased expenses.

Preoperative scoring can be an objective method to predict difficult case and could be better than the subjective guesswork. Various factors such as male sex, old age, upper abdominal tenderness, previous upper abdominal surgery, thick walled gall bladder and history of acute cholecystitis has been identified as a risk factors for conversion to open procedures. ${ }^{6-8}$ Similarly, elevated white blood cell counts, deranged liver function tests, low albumin level, co morbid illness such as diabetes mellitus, chronic obstructive airway disease, congestive cardiac failure and myocardial infarction has also attributed to difficult cholecystectomy. ${ }^{8-10}$

Randhawa and Pujahari have described a scoring system to predict a difficult laparoscopic cholecystectomy. ${ }^{2}$ They have developed a scoring system based on history, clinical examination and sonological findings to predict difficult cases with a total score of 15 . The pre-operative score from $0-5,6-10$ and more than 10 predicted easy, difficult and very difficult cases respectively. The prediction was true in $88.8 \%$ and $92 \%$ in easy and difficult cases respectively with a sensitivity and specificity of $75 \%$ and $90.24 \%$ respectively. The same scoring system was validated in a prospective study and found that the sensitivity and specificity of the scoring system was $95.74 \%$ and $73.68 \%$ respectively with positive predictive value for easy and difficult cases of $90 \%$ and $88 \%$ respectively. $^{3}$

We modified the scoring system proposed by Randhawa and Pujahari by adding biochemical parameters, history of co-morbid illness and contracted gall bladder to the scoring system because these factors are also known to be responsible for difficult cholecystectomy. 6,7,9 The parameters used in the scoring system does not incur any additional cost to the patient because these are based on history, physical examination and routinely done investigations for laparoscopic cholecystectomy.

For an easy case this scoring system had sensitivity of $89.2 \%$ which was comparable to $88.8 \%$ of Randhawa et al ${ }^{2}$ and $95.74 \%$ of Gupta et al. ${ }^{3}$ However for a difficult case the sensitivity of the scoring system in this study was $53.8 \%$ with specificity of $89.2 \%$ which was less than above two studies (92\% and 90.24\%).2,3 Area under curve for the prediction of the scoring system was .779 which is comparable to .81 and .86 in above two studies. ${ }^{2,3}$ Logistic regression showed that only three parameters (history of acute cholecystitis, gall bladder wall thickness and contracted gall bladder) were individually statistically significantly associated with prediction of difficult laparoscopic cholecystectomy. 
However, the scoring methods which incorporates all the known factors for difficult cholecystectomy does provide a definite, objective and reliable prediction of difficult case.

Recently a study suggested a risk score based on the history, physical examination and ultrasound of abdomen. ${ }^{4}$ They found that the level of difficulty correlated with the subjective perception of difficulty by operating surgeon ( $p<.0001, r=.915)$, length of procedure $(p<.01, r=.757)$. They used subjective perception of difficulty and operative time for assessing per-operative difficulty. However, in our study we used objective parameters to assess the difficulty which was adapted and modified from the system suggested by Randhawa and Pujahari. ${ }^{2}$
This is a single center study and the results may not be generalized. Results need to be validated in different centers and set up. Although the operating surgeons were blinded from the pre-operative score and prediction, performance bias cannot be ruled out.

\section{CONCLUSIONS}

Pre-operative prediction of difficult laparoscopic cholecystectomy is possible using a scoring method with a reasonable accuracy. Pre-operative prediction does have potential advantages for the surgeons, patients and patient's relatives.

\section{ACKNOWLEDGEIMENT}

We acknowledge Ethical Committee of Kathmandu Medical College Teaching Hospital for their support.

\section{REFERENCES}

1. Bulbuller N, Ilhan YS, Baktir A, Kirkil C, Dogru O. Implementation of a scoring system for assessing difficult cholecystectomies in a single center. Surg Today [Internet]. 2006 Jan [cited 2015 Feb 12];36(1):37-40. Available from: http://www.ncbi.nlm.nih.gov/pubmed/16378191

2. Randhawa JS, Pujahari AK. Preoperative prediction of difficult lap chole: a scoring method. Indian J Surg [Internet]. 2009 Aug [cited 2014 May 5];71(4):198-201. Available from: http://www.pubmedcentral.nih.gov/articlerender. fcgi ?artid=3452633\&tool=pmcentrez\&rendertype $=$ abstract

3. Gupta N, Ranjan G, Arora MP, Goswami B, Chaudhary P, Kapur A, et al. Validation of a scoring system to predict difficult laparoscopic cholecystectomy. Int J Surg [Internet]. Elsevier Ltd; 2013 Jan [cited 2014 May 5];11(9):1002-6. Available from: http://www.ncbi.nlm.nih.gov/ pubmed/23751733

4. Soltes M, Radoňak J. A risk score to predict the difficulty of elective laparoscopic cholecystectomy. Wideochirurgia i inne Tech mało inwazyjne $=$ Videosurgery other miniinvasive Tech / Kwart Pod patronatem Sekc Wideochirurgii TChP oraz Sekc Chir Bariatrycznej TChP [Internet]. 2014 Dec [cited 2015 Jan 14];9(4):608-12. Available from: http:/ / www. pubmedcentral.nih.gov / articlerender.fcgi?artid=4280432\&t ool $=$ pmcentrez\&rendertype $=$ abstract

5. Takegami K, Kawaguchi Y, Nakayama H, Kubota Y, Nagawa H. Preoperative grading system for predicting operative conditions in laparoscopic cholecystectomy. Surg Today [Internet]. 2004 Jan [cited 2014 May 5];34(4):331-6. Available from: http://www.ncbi.nlm.nih.gov/pubmed/15052448
6. Kama NA, Kologlu M, Doganay M, Reis E, Atli M, Dolapci M. A risk score for conversion from laparoscopic to open cholecystectomy. Am J Surg [Internet]. 2001 Jun [cited 2014 May 8];181(6):520-5. Available from: http://www.ncbi.nlm. nih.gov/pubmed/11513777

7. Lee NW, Collins J, Britt R, Britt LD. Evaluation of preoperative risk factors for converting laparoscopic to open cholecystectomy. Am Surg [Internet]. 2012 Aug [cited 2014 May 8];78(8):831-3. Available from: http://www.ncbi.nlm. nih.gov/pubmed/22856487

8. Schrenk P, Woisetschläger R, Rieger R, Wayand WU. A diagnostic score to predict the difficulty of a laparoscopic cholecystectomy from preoperative variables. Surg Endosc [Internet]. 1998 Feb [cited 2015 Jan 14];12(2):148-50. Available from: http://www.ncbi.nlm.nih.gov/pubmed/9479730

9. Lipman JM, Claridge J a, Haridas M, Martin MD, Yao DC, Grimes KL, et al. Preoperative findings predict conversion from laparoscopic to open cholecystectomy. Surgery [Internet]. 2007 Oct [cited 2014 May 5];142(4):556-63; discussion 563-5. Available from: http://www.ncbi.nlm. nih.gov/pubmed/17950348

10. Alponat A, Kum CK, Koh BC, Rajnakova A, Goh PMY. Predictive Factors for Conversion of Laparoscopic Cholecystectomy. World J Surg [Internet]. 1997 Jul [cited 2015 Feb 13];21(6):629-33. Available from: http://link. springer.com/10.1007/PL00012288 